\title{
Life jubilee of professor Rudolf Žáček
}

\author{
prof. PhDr. Dušan JANÁK, Ph.D.
}

In a time of ever narrower specialization, personages of broad outlook and diverse activities who can assert themselves across multiple professional fields become scarce. These rare exceptions include the Dean of the Faculty of Public Policies at the Silesian University in Opava, professor PhDr. Rudolf Žáček, Dr. The well-known historian, museum operator, university teacher and an experienced manager who after 1989 significantly contributed to the development of higher education and cultural life of the Moravian-Silesian Region, especially in Opava, has already celebrated his $70^{\text {th }}$ birthday in the spring of this year. Let us, therefore, at least briefly commemorate the essentials of his life and work, reminiscent in their breadth and depth of the engagement of Renaissance scholars, as professor Mečislav Borák ${ }^{1}$ has put it years ago.

Rudolf Žáček was born on 20 May 1948 in Ostrava-Vítkovice. After leaving secondary school in Ostrava, he studied History and Russian at the Philosophical Faculty of Palacký University in Olomouc in the years 1967-1971. For political reasons, he could not pursue scientific work in the field of modern history and started to work as a historian in the District Museum of National History in Frýdek-Místek. There he remained until 1989 when he transferred as a specialist to the Silesian Institute of the Czechoslovak Academy of Sciences in Opava and became its director in 1991. During the reduction of the Academy of Sciences of the Czech Republic in the spring of 1993, he contributed to the delimitation of the Institute as an independent research centre of the Silesian Museum where he served until 2007 among other positions also as the statutory deputy director of the museum. Already in 1991 he earned a doctoral degree and he started teaching at the Silesian University in Opava while also lecturing as an external lecturer at the philosophical faculties of University of Ostrava and the Palacký University in Olomouc where he became associate professor in

\footnotetext{
1 BORÁK, Mečislav: Rudolf Žáček - všestranný historik Slezska [Rudolf Žáček - The Versatile Historian of Silesia], in: Slezský sborník [Silesian Proceedings], 106, 2008, 3, 232-240. In addition to this informed analysis of Žáček's professional, particularly research, publishing and exhibition activities, see. e.g. ONDŘEKA, Zbyšek: Setkání s Rudolfem Žáčkem [Meeting Rudolf Žáček], in: Těšínsko [Cieszyn], 51, 2008, 3, 29-31, where a summary of the honoured man's articles in the magazine Těšínsko between the years 1973 and 2008 appears. For his full bibliography for this period, including a brief reminder of his life and fate, see ČAPSKÝ, Martin - ČAPSKÁ, Veronika: K životní dráze Rudolfa Žáčka [On the Life Path of Rudolf Žáček], in: Acta Universitatis Historica Silesianae Opaviensis 1, Confinia Silesiae (K životnímu jubileu Rudolfa Žáčka [Upon the Jubilee of Rudolf Žáček]), 2008, 13-14; JIRÁSEK, Zdeněk: Rudolf Žáček jubilující [Rudolf Žáček Jubilant], ibid., 15-16; Bibliografie Rudolfa Žáčka [Bibliography of Rudolf Žáček] (compiled by Markéta KOUŘILOVÁ), ibid., 17-28. Most recently, MÜLLER, Karel: Rudolf Ż́́ĆEK sedmdesátníkem [Rudolf ŽÁČEK Septuagenarian], in: Těšínsko [Cieszyn], 61, 2018, 1, 145-146.
} 
1999. The following year, he moved for full-time engagement to the Faculty of Philosophy and Science at the Silesian University in Opava, becoming vice-rector for study and social affairs in 2001 and appointed as the rector of University of Silesia by the President of the Czech Republic in 2007. In this capacity, he served until 2015, then moved to the Faculty of Public Policies of the Silesian University in the establishment of which he had played a significant role in 2008. There, he served as vice-dean for science and research, in charge of the leadership of the Department of Central European Studies, and he became the dean of this youngest part of the Silesian University in autumn 2016.

Throughout his activity at the Silesian University, he lectured at the Faculty of Philosophy and Science SU, later at the Faculty of Public Policies SU, and in April 2011, the President of the Czech Republic appointed him as Professor in the field of History, specializing in Czech and Czechoslovak history. Since the early 1990s, he worked in a variety of scientific and editorial boards and committees in the field of museum management and higher education at various levels. An overview of these domestic institutions has been assembled by M. Borák. ${ }^{2}$ Nowadays, he also remains member of numerous domestic and international expert committees. We may mention especially his long-term activity in the Conference of Rectors of Silesian Universities, consisting of four Polish and two Czech universities operating in the historical Silesia, in the foundation of which he participated in 2003 and over which he presided 2010-2015, currently being its honorary chairman. ${ }^{3}$

This way, he capitalized on his experience and long-term contacts with Polish academic and scholarly environment that is closely related to his lifelong research activities and publications. Their detailed analysis from the early 1970s to the end of the first decade of the new millennium has been performed by $\mathrm{M}$. Borák who distinguished eight basic topics ranging from the Middle Ages and Early Modern Era to the present, from economic, political or cultural history in different ways and periods to the area of auxiliary historical sciences, museum management and an assortment of other disciplines, from micro-probes into the history of towns and villages over the mapping of the transformations of the historic Silesia to the general considerations of international, especially Czechoslovak-Polish relationships and arrangements in Central Europe. ${ }^{4}$ We will therefore focus on the last decade in which we can distinguish three main research directions or currents within which he cooperated closely with professor Irena Korbelářová.

The first one is dedicated to the older and to a lesser extent the more recent history of Silesia and in the context of Czech-Polish relations and the development of Central Europe, or the transformation of Central European society. These include monographs on Cieszyn as a land of the Czech crown since the beginning of the principalities to the $18^{\text {th }}$ century, ${ }^{5}$ a set of cultural and historical biographical portraits of significant women of the Silesian history

2 BORÁK, 233.

3 Conference of Rectors of Silesian Universities - Konferencja Rektorów Uniwersytetów Śląskich is a platform for international scientific integration and a Czech-Polish scientific and educational cooperation forum, consisting of Uniwersytet Wrocławski, Uniwersytet Opolski, University of Silesia w Katowicach, Uniwersytet ekonomiczne w Katowicach, University of Ostrava and the Silesian University in Opava.

4 BORÁK, 233-240.

5 KORBELÁŘOVÁ, Irena - ŽÁČEK, Rudolf: Těšínsko - země Koruny české/Ducatus Tessinensis - terra Coronae Regni Bohemiae [Cieszyn - A Land of the Czech Crown/Ducatus Tessinensis - terra Coronae Regni Bohemiae], Český Těšín [Czech Cieszyn] 2008 (published 2009). 
in $15^{\text {th }}-18^{\text {th }}$ century, ${ }^{6}$ as well as a chapter focusing on the history of Silesia within the Czech state in the Baroque and Enlightenment periods. ${ }^{7}$ In this context, we should not forget the edition of statistical population survey in Austrian Silesia in the $18^{\text {th }}$ century. ${ }^{8}$ The honoured professor's wide time engagement and orientation in various problem areas is confirmed in his considerations about the beginning of the history of Upper Silesia ${ }^{9}$ on the one hand, and by his contribution on the organization of the Church administration in the Czechoslovak Silesia in the 1980s on the other hand, which appear in the collective monograph on the history of the Ostrava-Opava diocese for which he led the team of authors. ${ }^{10}$

The second thematic area represent contributions in collective monographs and journal studies on the history of Silesian towns and villages in the early modern period, especially in the Opava region. This includes both work on the nature and status of Hradec nad Moravicí and Opava and in this period, ${ }^{11}$ and probes into the lives of various social groups and strata, especially the burghers. ${ }^{12}$

Nearly all of the above works to some extent touch upon the cultural-historical issues and contexts which together with material culture constitute a third distinct thematic area, ranging chronologically from the beginning of the early modern period to the present day, to which the celebrated professor has been paying attention in recent years. Besides the broader consideration of the specific features of material culture of Austrian Silesia, ${ }^{13}$ it is again a number of studies prepared jointly with Irena Korbelářová. The earlier period is dealt with in the case study of courtly ceremonies of the last Piasts or the burial portrait of Anne of Luxembourg, ${ }^{14}$ the more recent period appears in a study on Silesian pilgrimages

6 Ibid., De illustribus Feminis Sielsiae. O znamenitých ženách Slezska 15.-18. století [De illustribus Feminis Sielsiae. The Exquisite Women of Silesia 15 $15^{\text {th }} 18^{\text {th }}$ century], Matice slezská [Silesian Publishing], Opava 2013.

7 lbid., Od baroka k osvícenství [From the Baroque to the Enlightenment], in: Slezsko v dějinách českého státu, II, 1490-1763 [Silesia in the History of the Czech State, II, 1490-1763], Prague 2012, 137-301, 416-472.

8 Obyvatelstvo Rakouského Slezska v pozdně osvícenském období [The Population of Austrian Silesia in the Late Enlightenment Period], KORBELÁŘOVÁ, Irena - ŽÁČEK, Rudolf (eds.), Opava 2012.

9 ŽÁČEK, Rudolf: Górny Śląsk na progu historii, in: Historia Górnego Śląska. Politika, gospodarka i kultura europejskiego regionu, BAHLCKE, Joachim - GAWRECKI, Dan - KACZMAREK, Ryszard (eds.), Gliwice 2011, 97-116.

10 ŽÁČEK, Rudolf: K územní struktuře a organizaci církevní správy v československém Slezsku před ustavením ostravsko-opavské diecéze (80. léta 20. století) [On the Territorial Structure and Organization of Church Administration in Czechoslovakian Silesia Before the Establishment of the Ostrava-Opava Diocese $\left(80^{\text {th }}\right.$ Years of the $20^{\text {th }}$ Century)], in: Ostravsko-opavská diecéze. Kořeny a souvislosti [Ostrava-Opava Diocese. Roots and Context], ŽÁČEK, Rudolf et al., Opava 2013, 92-117

11 KORBELÁŘOVÁ, Irena - ŽÁČEK, Rudolf: Raně novověký Hradec: město, anebo rustikální lokalita s městskými právy? [Early Modern Hradec: A Town, or a Rural Location with Town Rights?], in: Hradec v dějinách [Hradec In the History], JIRÁSEK, Zdeněk et al., Hradec nad Moravicí 2010, 44-86; ŽÁČEK, Rudolf: Postavení Opavy mezi slezskými městy v první polovině 18. století [Position of Opava in the Context of Silesian Cities in the First Half of the $18^{\text {th }}$ Century], in: Mesto a dejiny [City and History], 1, 2012, 1-2, 158-164.

12 KORBELÁŘOVÁ, Irena - ŽÁČEK, Rudolf: Opavští erbovní měštané předbělohorské doby. Prolegomena k výzkumu [Armorial Burghers of Opava of the Period After the Battle of White Mountain. Prolegomena for Research], in: Slezský sborník [Silesian Proceedings], 113, 2015, 5-21; Ibid., Majitelé litultovického statku v 16. a 17. století [Owners of the Litultovice Farmhouse in the $16^{\text {th }}$ and $17^{\text {th }}$ Century], in: Litultovice 1317-2017, KOLÁŘr, Ondřej (ed.), Opava - Litultovice 2017, 12-55.

13 ŽÁČEK, Rudolf: Národní a regionální specifika v materiální kultuře Rakouského Slezska [National and Regional Specificities in the Material Culture of Austrian Silesia], in: Realia zycia codziennego w Europie Środkowej ze szczególnym uwzglednieniem Śląska. Zabrza, seria naukowa Kultura Europy Środkowej, tom XIV, Katowice-Zabrze 2011, 395-404.

14 KORBELÁŘOVÁ, Irena - ŽÁČEK, Rudolf: "... I přisedl vévoda do vozu ke knížecí nevěstě..." Příspěvek 
in the second half of the $18^{\text {th }}$ century, on how Emperor Franz I. viewed the Opava Grammar School Museum, or on the hospitality facilities of Opava in the second half of the $19^{\text {th }}$ century. ${ }^{15}$ The most recent was the interesting and factually rich monograph on the development of university buildings, significant by its contribution to the history of architecture in Opava, which was followed by an independent study on abuilding in Masaryk Sreet in Opava. ${ }^{16}$

The aforementioned research and publication activities are closely related to the part the professor took in teaching the Master's study program Cultural Heritage in Regional Practice at the Faculty of Science and Philosophy SU for which he and I. Korbelárová had prepared an interesting textbook ${ }^{17}$ and which also contributed to some instruction in the Bachelor's and Master's study programs in the field of Middle European Studies at the Faculty of Public Policies. Likewise, these activities were associated with his editorial work in the journal Cieszyn whose managing editor he has been since 1993, and in other journals where he is long-standing member of editorial boards, such as Silesian Proceedings, Magazine of the Silesian Land Museum, series B, Acta Historica Universitatis Silesianae Opaviensis Papers and Central European Papers the founding of which he greatly supported as the rector of the University of Silesia. The general public were able to learn about the results of this research primarily through thematic exhibitions organized at various occasions, such as e.g. the 2016 exhibition on the history of the university buildings at the opening of the new building of the Faculty of Public Policies in 14 Bezruč Square, Opava.

A deeper appreciation of the celebrated professor's extensive work is yet to come in future generations. However, a brief reminder of his main activities has shown that despite the demands of the university offices, his work is far from being closed, that professor Žáček is asking himself more and more new questions and seeking answers to problems of cultural history and Silesian history in the Central European context which have not been investigated yet. Let us hope that this work will continue and that we can look forward to many

k poznání dvorských ceremoniálů posledních Piastovců na př́ikladu Jiř́ho III. Břežského ["... Thus the Duke Sat in the Chariot to Join the Princely Bride..." Contribution to the Knowledge of Court Ceremonies of the Last Piasts on the Example of George III. of Brieg], in: Acta Historica Universitatis Silesianae Opaviensis, 2012, 4, 175-197; KORBELÁŘOVÁ, Irena - ŽÁČEK, Rudolf - DLUHOŠOVÁ, Radmila: " ... tělesně krásná a s tváří jemnou a pưvabnou..." Funerální portrét Anny Lucemburské, urozené chráněnky knížete Přemka I. Těšínského na cestě do Anglie ["... physically beautiful with a face soft and lovely..." Funeral portrait of Anne of Luxembourg, the Noble Protegé of Prince Přemek I. of Cieszyn on the Way to England], in: Těšínsko [Cieszyn], 57, 2014, 2, 1-12.

15 KORBELÁŘOVÁ, Irena - ŽÁČEK, Rudolf: Poutě ve slezské části olomoucké diecéze ve 2. polovině 18. století [Pilgrimages in the Silesian Part of the Olomouc Diocese in the $2^{\text {nd }}$ Half of the $18^{\text {th }}$ Century], in: Acta Universitatis Silesianae Opaviensis 8, 2015, 27-48; Ibid., Obraz opavského gymnazijního muzea v osobních výpovědích císaře Františka I. [The Image of Opava Grammar School Museum in the Personal Testimonies of Emperor Franz I.], in: Časopis Slezského zemského muzea [Journal of the Silesian Museum], series B, 65, 2016, 233-240; ŽÁČEK, Rudolf - STUCHLÍKOVÁ, Jana: Opavská pohostinství ve světle nejstarších adresářu z druhé poloviny 19. století [Hospitality Facilities of Opava in the Light of the Oldest Directories from the $2^{\text {nd }}$ Half of the $19^{\text {th }}$ Century], in: Kulinární kultura Slezska a střední Evropy. Východiska, metody, interdisciplinarita [Culinary Culture of Silesia and Central Europe. Background, Methods, Interdisciplinarity], KORBELÁŘOVÁ, Irena et al., Opava 2015, $175-188$.

16 KORBELÁŘOVÁ, Irena - ŽÁČEK, Rudolf: Kořeny i křídla. K historii opavských univerzitních budov [Roots and Wings. On the History of the University Buildings of Opava], Opava 2016; Ibid., Ad Fontes! Několik upřesňujících poznámek k historickému vývoji objektu č. 343/37 na Masarykově třídě v Opavě v letech 1784 až 1837 [Ad Fontes! A Few Specifying Remarks on the Historical Development of the Building no. 343/37 in Masaryk Street in Opava in the Years 1784-1837], in: Acta Historica Universitatis Silesianae Opaviensis, 2017, 10, 51-67.

17 KORBELÁŘOVÁ, Irena - ŽÁČEK, Rudolf: Úvod do dějin a kulturního dědictví Slezska [Introduction to the History and Heritage of Silesia], Opava 2015. 
more of his creative achievements. On behalf of the editors and readers of our journal and of its cooperators at the faculty and university, we wish him good health and creative vigour for the years to come.

\section{Author}

prof. PhDr. Dušan Janák, Ph.D.

Ústav středoevropských studií, Fakulta veřejných politik v Opavě, Slezská univerzita v Opavě Institute of Central European Studies, Faculty of Public Policies in Opava, Silesian University in Opava

Bezručovo náměstí 885/14, 74601 Opava, Czech Republic dusan.janak@fvp.slu.cz 